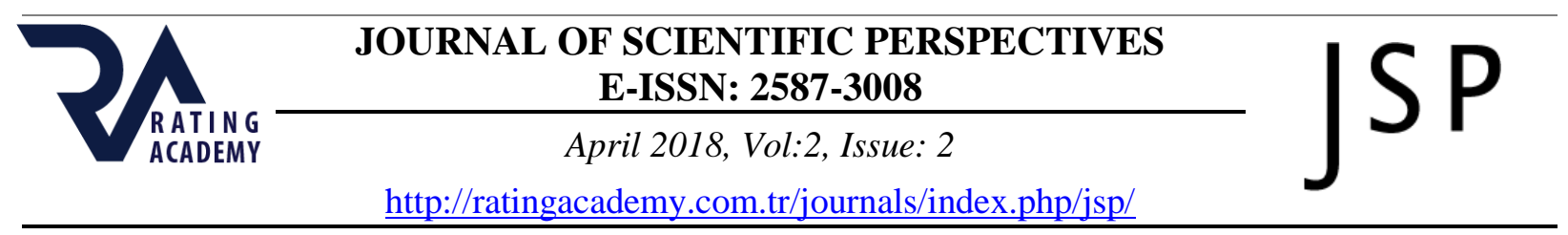

\title{
INOS IMMUNOREACTIVITY IN THE OVARIES OF RATS FEEDING WITH MUSSEL (Mytilus galloprovincialis)
}

\author{
Assist. Prof. Dr. Mehmet Riza GEZEN" \\ Canakkale Onsekiz Mart University, Canakkale,Turkey,E-mail: mrgezen@comu.edu.tr
}

Dr. Aslı MURATLI

Baskent University, Izmir, Turkey

Servet Özden HACIVELIOĞLU

Canakkale Onsekiz Mart University, Canakkale, Turkey

\begin{tabular}{l} 
ARTICLE INFO \\
\hline Article History: \\
Received: 19 March 2018 \\
Accepted:26 April 2018 \\
\\
Keywords: Dardanelles, \\
mussel, inducible nitric oxide \\
synthase, rat, ovary.
\end{tabular}

DOI: $10.26900 / j s p .2018 .13$

\begin{abstract}
The ovary is an endocrine and exocrine gland that plays primary role in female development and reproductive activities. The seamen are collecting a lot of heavy metals by serving as filters in the seas. Since the last decades of the nineteenth century and until today, the study of the consequences of human exposure to heavy metals has risen as a central research area in the toxicological field. Among the group of metals with proven human toxicity aluminum $(\mathrm{Al})$ and lead $(\mathrm{Pb})$ are known to be highly neurotoxic. The Mediterranean mussel (Mytilus galloprovincialis) is a species of bivalve, a marine mollusc in the family Mytilidae. In our previous researches, we found $\mathrm{Al}$, zinc $(\mathrm{Zn})$ and iron $(\mathrm{Fe})$ values were higher in mussels taken from Çamburnu region of the Dardanelles. In many tumors, inducible nitric oxide synthase (iNOS) expression is high, however, the role of iNOS during tumor development is very complex and quite perplexing, with both promoting and inhibiting actions having been described. The purpose of the study is to demonstrate the iNOS immunoreactivity in the ovarian tissues of rats which are fed with mussels that are collected from the Çamburnu region of the Dardanelles. The mussels given as food to the rats were removed from the Çamburnu region of the Dardanelles. Average $100 \pm 10 \mathrm{~g}$ weight were selected. After the beaks were overcooked, the meat broke off and the meat at 100 degrees was dried. Two groups of rats are included in the study, group $1(n=6)$, control group fed with standard rat food, group $2(n=6), 90 \%$ mussels and 10\% standard rat food daily. To detect iNOS localization in the tissues, the LAB-SA Detection System was used. iNOS immunoreactivity was detected in the interstitial cell cytoplasm of the ovaries of rats fed with mussel. iNOS immunoreactivity was also observed in germ cell cytoplasm in some primordial follicles. There was statistically significant difference between the iNOS immunoreactivity of the interstitial cells in the ovarian parenchyma of the rats in the experimental and control groups $(p>0.05)$.
\end{abstract}

ABSTRACT

\section{INTRODUCTION}

$\mathrm{Pb}$ is a heavy metal with no known biological function in humans. On the contrary, it can damage various systems of the body including the hematopoietic, renal and skeletal systems with the central nervous system being its primary target [Wilson et all., 2000]. The susceptibility to $\mathrm{Pb}$ toxicity is influenced by several factors such as environmental exposure, age and nutritional status. Human exposure to $\mathrm{Pb}$ occurs via food, water, air and soil. Food 
and water $\mathrm{Pb}$ sources include the use of $\mathrm{Pb}$-containing ceramic dishware, metal plumbing, and food cans that contain $\mathrm{Pb}$ solder (White et al., 2007).

Oxidative stress, oxidative damage to cellular components, and the activation of oxidant sensitive transcription factor could in part underlie some of the toxic effects of $\mathrm{Pb}$. The deleterious effects of $\mathrm{Pb}$ can involve both, ROS and reactive nitrogen species. Oxidative stress has been associated with $\mathrm{Pb}$ exposure in humans and in experimental animal models. In humans occupationally exposed to $\mathrm{Pb}$, biomarkers of oxidative stress such as malondialdehyde, GSH status, glutathione peroxidase and catalase, exceeded the mean value of the control population (Costa et al., 1997; Garcon et al., 2004; Devi et al., 2007).

The interference with nitric oxide production might represent another mechanism accounting for $\mathrm{Pb}$ neurotoxicity. $\mathrm{Pb}$ affects neuronal nitric oxide synthase (nNOS) in the developing rat brain. Rats perinatally exposed to $\mathrm{Pb}$ had decreased nNOS protein levels and activity in cerebellum and hippocampus at PND 21 and 35 as compared to their age-matched controls (Chetty et al., 2001).

In general, perinatal rat exposure to low levels of $\mathrm{Pb}$ causes an increased sensitivity of brain dopamine D2 and D3 receptors (Cory-Slechta et all. 1992; Gedeon et al., 2001), increased hippocampal activity of tyrosine hydroxylase [Bielarczyket et all., 1998], produces higher levels of dopamine (Leret et all., 2002; Devi et al., 2005), and enhances catecholaminergic neurotransmission in cerebral cortex, hippocampus and cerebellum due to increased turnover of norepinephrine (Devi et al., 2005). On the otherhand, perinatal exposure to high $\mathrm{Pb}$ concentrations decreases norepinephrine, epinephrine and dopamine levels in the cerebral cortex, hippocampus and cerebellum (Devi et al., 2005; Dubas et al., 1978; Sidhu et al., 2003), and decreases the activities of acetylcholinesterase (Sidhu et al., 2003), monoamino oxidase (Devi et al., 2005), and tyrosine hydroxylase (Mc Intosh et al., 1989).

Lead intoxication has been shown to promote atherosclerosis in experimental animals. There are also indications that chronic lead exposure may affect systemic lipid metabolism (Reviset al., 1981). Current evidence on lead-induced oxidative stress has been based mostly on in vitro experiments (Ding et al., 2000) or studies conducted in animals (Fowler et al., 2004).

In this study, it was aimed to determine the iNOS immunoreactivity in the ovarian tissue of rats fed with mussels containing heavy metal salts.

\section{MATERIAL AND METHODS}

\subsection{Ethics Statement}

A total of 12 female Wistar albino rats, weighing $300 \pm 10 \mathrm{~g}$, were used in the study. The study protocol was approved by the Çanakkale Onsekiz Mart University Ethics Committee for Animal Research (ÇOMÜ- HADYEK / 2011-08-08).

\subsection{Animal Model}

The rats were kept for 30 days under appropriate conditions of temperature/humidity and a 12-h light cycle while being provided sufficient water and feed. The rats were randomly selected and divided into 2 groups. The first group (n: 6) was the control group; standard rat diet. Experimental group (n: 6); $90 \%$ mussel $+10 \%$ standard rat diet. Rats were fed twice daily for 30 days at $15 \%$ of their weight every morning and evening at the same time. The mussels given as food to the rats were removed from the Dardanelles Çamburnu region (Photo 1). Average $100 \pm 20 \mathrm{~g}$ weight were selected. After the beaks were overcooked, the meat broke off and the meat at 100 degrees was dried.

It was weighed into each rat's weight and $10 \mathrm{mg} / \mathrm{kg}$ intraperitoenal ketamine hydrochloride (Ketalar, Eczacibasi, Istanbul, Turkey), and $20 \mathrm{mg} / \mathrm{kg}$ of alfazyne $2 \%$ (Rompun, Bayer Turkey Pharmaceutical Ltd., Istanbul, Turkey) were anesthetized and taken right ovary. 
The rats, which had been hatchlings, were treated after the operation and delivered to the animal shelter for further investigations.

\subsection{Histological evaluation}

The ovarian tissues were maintained in immunofix (Leica) for 24 hours for histopathological examination. The paraffin embedded ovarian tissues were stained with hematoxylin and eosin $(\mathrm{H} \& \mathrm{E})$ at a thickness of 5 microns. Immunohistochemical staining method was applied by cutting the paraffin embedded ovarian tissues 3 microns in thickness. The LAB-SA Detection System, (Histostain-Plus Bulk Kit, Invitrogen) was applied to determine immunohistochemical localization of iNOS enzyme in tissues. Sections taken from paraffin blocks were deparaffinized and rehydrated. Subsequently, 3\% $\mathrm{H}_{2} \mathrm{O}_{2}$ was applied to the sections to block endogenous peroxidase activity.

The sections were incubated in citrate buffer $(0.1 \mathrm{M}, \mathrm{pH}: 6.0)$ in the microwave $(800$ watts, $10 \mathrm{~min}$ ) for antigen retrieval, and the samples were washed with phosphate buffer solution (PBS, 0.1 M, pH 7.2). After the samples had been incubated in the blocking buffer for $10 \mathrm{~min}$, they were washed with PBS. Next, slides were incubated with anti-iNOS (inducible nitric oxide synthase) antibody (anti-NOS2, Santa Cruz Biotechnology), which was diluted at 1: 400 for the ovarium, for an hour at room temperature, and they were then washed with PBS. Afterwards, biotinylated secondary antibody was applied to the samples for $30 \mathrm{~min}$ (Ultravision Detection System, Thermo Scientific, Fremont, USA). Then the samples were washed with PBS again and incubated with Broad Spectrum Antibody (Invitrogen, USA) for 30 min. After washing the samples, diaminobenzadine-tetrahydrochlorid (DAB, Invitrogen Corporation) was applied to them. Negative control was used to determine specific iNOS immunoreactivity, and hematoxylin stain was used as a nuclear counter stain.

Dye samples were evaluated on the Zeiss AXIO Scope 1 brand research microscope. Analysis of iNOS immunoreactive cells in the ovarium parenchyma was performed using the Leica LAS V3.8 image analysis system. The Mann Whitney U-test was used the Non Parametric tests to determine the differences between the experimental group and the control group.

\section{RESULT}

In the ovarian tissue samples from the rats in the experimental groups, extensive positive iNOS immunoreactivity was observed in the interstitial cell (Figure 1) and germ cell cytoplasm in the primordial follicle (Figure 2) when the anti-NOS2 antibody was applied.

iNOS immunoreactivity was not observed in the same tissue samples without iNOS antibody (Figure 3).

Positive iNOS immunoreactivity was not detected in the ovarian tissue samples from rats in the control group when anti-NOS2 antibody was applied (Figure 4).

Statistical Analysis

There was statistically significant difference between the iNOS immunoreactivity of the interstitial cells in the ovarian parenchyma of the experimental and control groups $(\mathrm{p}>$ $0.05)$.

\section{CONCLUSION}

In our study, positive iNOS immunoreactivity was detected in germ cell cytoplasm in interstitial cells and primordial follicles in the ovaries of rats fed with mussels containing heavy metal salts such as lead, copper, aluminum, zinc and iron.

Various in vitro and in vivo studies have explored the underlying mechanisms by which chronic low level lead exposure can raise arterial pressure, thereby cardiovascular disease (CVD) development. These studies have identified the involvement of oxidative stress and inflammation 
(Vaziri et al., 1997), by promoting endothelial dysfunction (Vaziri et al., 1995), promoting vascular smooth muscle cells proliferation and transformation (Fujiwara et al., 1995), and impairing NO homeostasis (Ding et al., 1998).

iNOS catalyzes the production of NO, which has an important role in the maintenance of vascular regulation and immune system (Willerson et al., 2004).

Heavy metals are toxic because they may have cumulative deleterious effects that can cause chronic degenerative changes [Ibrahim et all., 2006], especially to the nervous system, liver, and kidneys, and, in some cases, they also have teratogenic and carcinogenic effects (IARC 1987). The mechanism of toxicity of some heavy metals still remains unknown, although enzymatic inhibition, impaired antioxidants metabolism, and oxidative stress may play a role. Heavy metals generate many of their adverse health effects through the formation of free radicals, resulting in DNA damage, lipid peroxidation, and depletion of protein sulfhydryls (e.g., glutathione) (Valko et al., 2005).

Although not fully proven, $\mathrm{Al}$ accumulation in the brain is proposed to be associated with neurodegenerative diseases, including Alzheimer's dementia, Parkinson's disease, amyotrophic lateral sclerosis, and dialysis encephalopathy (Gonçalves et al., 2007). Nutritional status is another significant risk factor for $\mathrm{Pb}$ intoxication and its effects. Iron, zinc and calcium deficiencies increase the retention of ingested $\mathrm{Pb}$, which can also increase $\mathrm{Pb}$ gastrointestinal absorption (Goyer, 1996; Ruff et al., 1996), and affect the susceptibility to Pb neurotoxicity (Aimo et al., 2006). Human exposure to $\mathrm{Al}$ is mainly caused by environmental factors, such as soil contamination (Yokel et al., 2008). Al absorption are the gastrointestinal tract (Ittel, 1993).

Minerals play a critical role in iNOS expression. High levels of copper increase iNOS expression in lung, liver, and aorta (Cuzzocrea et al., 2003), thus demonstrating thsatexessive copper can have detrimental effects on both constitutive and inducible NO synthesis. The combined effects of increased iNOS expression and decreased eNOS activity in the same anatomical location could have profound consequences on inflammatory processes of cells within the cardiovascular bed. Iron either increases iNOS expression in macrophages and proximal tubules (Chen et al., 2001) or suppresses elevated iNOS protein levels in the hearth and kidney ( $\mathrm{Ni}$ et al., 1997). Thus, iron excess or deficiency can impair immunlogical, cardiovascular, and renal function. In addition, zinc modulates iNOS expression in the small intestine, thereby preventing cytokine-induced diarrhea (Cui et al., 1997). In addition, chromium and lead inhibit, but nickel and cobalt incresae, iNOS expression in activated macrophages (Tian et al., 1996), suggesting an important role for NO in mediating the cytotoxic effects of environmental contamination by metals.

In pathological conditions, nitric oxide (NO) is a molecule of nitric oxide synthase (NOS) synthesized from L-arginine, which has a short potent free radical structure. As a result of high NOS production in pathological conditions, NO becomes neurotoxic and plays a role as cytotoxic molecule in the progress of secondary damage as a free radical.

Our previous researches have shown that some mollusc species such as mussels grown in the Dardanelles, sea grass, sea chestnut, aquiva, and heavy metals such as iron, zinc, aluminum, lead and copper are found in sea water (Demir et al., 2011; Gezen et al. 2011; Ozkurnaz et al., 2012; Gezen et al. 2011).

In our work, detection of positive iNOS immunoreactivity in germ cell cytoplasm of interstitial cells and primordial follicles in the ovaries of rats fed with mussels containing heavy metal salts such as lead, copper, aluminum, zinc and iron in our study suggests that heavy metal salts may promote iNOS release.

The ovary is one of the endocrine glands that plays an important role in the maintenance of the reproductive activities [Carr, 1998]. The presence of iNOS immunoreactivity in these cells is thought to impair the production of gonadal hormones secreted from these cells and may result in low fertility results. 
GEZEN et al. / iNOS Immunoreactivity in The Ovaries of Rats Feeding with Mussel (Mytilus galloprovincialis)

\section{Footnotes}

**At the time of this research, Dr. Asl1 MURATLI was working at Department of Pathology of Çanakkale Onsekiz Mart University. 


\section{REFERENCES}

AIMO, L., OTEIZA, P.I., 2006, Zinc Deficiency Increases the Susceptibility of Human Neuroblastoma Cells to Lead-Induced Activator Protein-1 Activation. Toxicol Sci, 91, 184-191.

BIELARCZYK, H., TOMASZEWICZ, M., SZUTOWICZ, A., 1998, Effect of Aluminum on Acetyl-CoA and Acetylcholine Metabolism in Nerve Terminals. J Neurochem, 70(3), 1175-1181.

CARR, B.R., BLACKWELL, R.E., 1998, Textbook of Reproductive Medicine, Stamford, CT, Appleton \& Lange.

CHEN, L., WANG Y., KAIRAITIS, L.K., ZHANG, B.H., HARRIS, D.C., 2001, Molecular Mechanisms by which Iron Induces Nitric Oxide Synthesis in Cultured Proximal Tubule Cells. Exp Nephrol, 9(3), 198-204.

CHETTY, C.S., REDDY, G.R., MURTHY, K.S., JOHNSON, J., SAJWAN, K., DESAİAH D., 2001, Perinatal Lead Exposure Alters the Expression of Neuronal Nitric Oxide Synthase in Rat Brain. Int J Toxicol, 20, 113-120.

CORY-SLECHTA, D.A., POKORA, M.J., WIDZOWSKI, D.V., 1992, Postnatal Lead Exposure Induces Supersensitivity to the Stimulus Properties of a D2-D3 Agonist. Brain Res, 598, 162-172.

COSTA C.A., TRIVELATO G.C., PINTO A.M., BECHARA E.J., 1997, Correlation between Plasma 5 Aminolevulinic Acid Concentrations and Indicators of Oxidative Stress in Lead-Exposed Workers. Clin Chem, 43 (7), 1196-1202.

CUI L., TAKAGI Y., WASA M., IIBOSHI Y., KHAN J., NEZU R., OKADA A., 1997, Induction of Nitric Oxide Synthase in Rat Intestine by Interleukin-1 Alpha May Explain Diarrhea Assciated with Zinc Deficiency. J Nutr, 127, 1729-1736.

CUZZOCREA S., PERSICHINI T., DUGO L., COLASANTI M., MUSCI G., 2003, Copper Induces Type II Nitric Oxide Synthase in Vitro. Free Radical Biol Med, 34(10), 12531262.

DEMIR N., GEZEN M.R., BALLI M., 2011, Çanakkale Boğazı'nın Karacaören Kıyısındaki Deniz Suyu ve Bazı Yumuşakçalarda (Bivalvia ve Gastropoda) Ağır Metal Düzeylerinin Araştırılması. Ekoloji Sempozyumu, Düzce, 177.

DEVI C.B., REDDY G.H., PRASANTHI R.P., CHETTY C.S., REDDY G.R, 2005, Developmental Lead Exposure Alters Mitochondrial Monoamine Oxidase and Synaptosomal Catecholamine Levels in Rat Brain. Int J Dev Neurosci, 23, 375-381.

DEVI S.S., BISWAS A.R., BISWAS R.A., VINAYAGAMOORTHY N., KRISHNAMURTHI K., SHINDE V.M., HENGSTLER J.G., HERMES M., CHAKRABARTI T., 2007, Heavy Metal Status and Oxidative Stress in Diesel Engine Tuning Workers of Central Indian Population. J Occup Environ Med, 49(11): 1228 1234.

DING Y., VAZIRI N.D., GONICK H.C.,1998, Lead-Induced Hypertension. II. Response to Sequential Infusions of L-Arginine, Superoxide Sismutase, and Sitroprusside. Environmental Research, 76(2), 107-113.

DING Y., GONICK H.C., VAZIRI N.D., 2000, Lead Promotes Hydroxyl Radical Generation and Lipid Peroxidation in Cultured Aortic Endothelial Cells. The American Journal of Hypertension, 13(5), 552-555.

DUBAS T.C., HRDINA P.D., 1978, Behavioural and Neurochemical Consequences of Neonatal Exposure to Lead in Rats. J Environ Pathol Toxicol, 2, 471-484.

FOWLER B.A., WHITTAKER M.H., LIPSKY M., WANG G., CHEN X.Q., 2004, Oxidative Stress Induced by Lead, Cadmium and Arsenic Mixtures: 30-day, 90-day, and 180-day Drinking Water Studies in Rats: An Overview. BioMetals, 17(5), 567-568. 
FUJIWARA Y., KAJI T., YAMAMOTO C., SAKAMOTO M., KOZUKA H., 1995, Stimulatory Effect of Lead on the Proliferation of Cultured Vascular Smooth-Muscle Cells. Toxicology, 98, 105-110.

GARCON G., LELEU B., ZERIMECH F., MAREZ T., HAGUENOER J.M., FURON D., SHIRALI P., 2004, Biologic Markers of Oxidative Stress and Nephrotoxicity as Studied in Biomonitoring of Adverse Effects of Occupational Exposure to Lead and Cadmium. J Occup Environ Med, 46, 1180-1186.

GEDEON Y., RAMESH G.T., WELLMAN P.J., JADHAV A.L., 2001, Changes in Mesocorticolimbic Dopamine and D1/D2 Receptor Levels after Low Level Lead Exposure: a Time Course Study. Toxicol Lett, 123, 217-226.

GEZEN M. R, DEMIR N., ÇETIN M., 2011 Çanakkale Boğazı'nın Umurbey Kıyısındaki Deniz Suyu ve Bazı Y.umuşakçalarda (Bivalvia ve Gastropoda) Ağır Metal Düzeylerinin Araştırılması. Ekoloji Sempozyumu, Düzce, 178.

GEZEN M.R., DEMIR N., ÇETIN M., BALLI M., 2011, Çanakkale Boğazı'ndaki Deniz Kestanesi (Paracentrotus lividus)' nin Ağır Metal Düzeyleri Üzerinde Bir Araştırma. Ekoloji Sempozyumu, Düzce, 176.

GONÇALVES P.P., SILVA V.S., 2007, Does Neurotransmission Impairment Accompany Aluminium Neurotoxicity? J Inorg Biochem, 101 (9), 1291-1338.

GOYER R.A., 1996, Results of Lead Research: Prenatal Exposure and Neurological Consequences. Environ Health Perspect, 104 (10), 1050-1054.

IARC (International Agency for Research on Cancer) 1987, Monographs on the Evaluation of the Carcinognic Risk of Chemicals to Humans: Arsenic and Arsenic Compounds (Group 1), vol. 7, World Health Organization, Lyon, France, 100-106.

IBRAHIM D., FROBERG B., WOLF A., AND RUSYNIAK D.E., 2006, Heavy Metal Poisoning: Clinical Presentations and Pathophysiology. Clinics in Laboratory Medicine, 26 (1), 67-97.

ITTEL T.H., 1993, Determinants of Gastrointestinal Absorption and Distribution of Aluminium in Health and Uraemia. Nephrol Dial Transplant, 8(1), 17-24.

KAJI T., SUZUKI M., YAMAMOTO C., MISHIMA A., SAKAMOTO M., KOZUKA H., 1995, Severe Damage of Cultured Vascular Endothelial Cell Monolayer after Simultaneous Exposure to Cadmium and Lead. Archives of Environmental Contamination and Toxicology, 28, 168-172.

LERET M.L., GARCIA-UCEDA F., ANTONIO M.T., 2002, Effects of Maternal Lead Administration on Monoaminergic, GABAergic and Glutamatergic Systems. Brain Res Bull, 58(5), 469-473.

MC INTOSH MJ., MEREDITH P.A., MOORE M.R., GOLDBERG A., 1989, Action of Lead on Neurotransmission in Rats. Xenobiotica, 19(1), 101-113.

NI Z., MORCOS S., VAZIRI N.D., 1997, Up-Reulation of Renal and Vascular Nitric Oxide Synthase in Iron-Deficiency Anemia. Kidney Int, 52(1), 195-201.

OZKURNAZ G., DEMIR N., 2012, Umurbey Bölgesi'nden (Çanakkale) Toplanan Mytilus Galloprovincialis ve Pecten Maximus Dokularında Ağır Metal Birikiminin İncelenmesi. 21. Ulusal Biyoloji Kongresi, Izmir, 880-881.

REVIS N.W., ZINSMEISTER A.R., BULL R., 1981, Atherosclerosis and Hypertension Induction by Lead and Cadmium Ions: An Effect Prevented by Calcium Ion. Proceedings of the National Academy of Sciences of the United States of America, 78(10), 6494-6498.

RUFF H.A., MARKOWITZ M.E., BIJUR P.E., ROSEN J.F., 1996, Relationships Among Blood Lead Levels, Iron Deficiency, and Cognitive Development in Two-Year-Old Children. Environ Health Perspect, 104, 180-185. 
SIDHU P., NEHRU B., 2003, Relationship Between Lead-Induced Biochemical and Behavioral Changes with Trace Element Concentrations in Rat Brain. Biol Trace Elem Res, 92, 245-256.

TIAN L., LAWRENCE D.A., 1996 Metal-Induced Modulation of Nitric Oxide Productionin Vitro by Murine Macrophages: Lead, Nickel, and Cobalt Utilize Different Mechanisms. Toxicol Appl Pharmacol, 141(2), 540-547.

VALKO M., MORRIS H., CRONIN M.T., 2005, Metals, Toxicity and Oxidative Stress. Current Medicinal Chemistry, 12 (10), 1161-1208.

VAZIRI N.D., DING Y., NI Z., GONICK H.C., 1997, Altered Nitric Oxide Metabolism and Increased Oxygen Free Radical Activity in Lead Induced Hypertension: Effect of Lazaroid Therapy. Kidney International, 52 (4), 1042-1046.

WHITE L.D., CORY-SLECHTA D.A., GILBERT M.E., TIFFANY-CASTIGLIONI E., ZAWIA N.H., VIRGOLINI M., ROSSI-GEORGE A., LASLEY S.M., QIAN Y.C., BASHA M.R., 2007, New and Evolving Concepts in the Neurotoxicology of Lead. Toxicol Appl Pharmacol, 225(1), 1-27.

WILLERSON J.T., RIDKER P.M., 2004, Inflammation as a Cardiovascular Risk Factor. Circulation, 109, II2-10.

WILSON M.A., JOHNSTON M.V., GOLDSTEIN G.W., BLUE M.E., 2000, Neonatal Lead Exposure Impairs Development of Rodent Barrel Field Cortex. Proc Natl Acad Sci USA, 97(10), 5540-5545.

YOKEL R.A., HICKS C.L., FLORENCE R.L., 2008, Aluminum Bioavailability from Basic Sodium Aluminum Phosphate, an Approved Food Additive Emulsifying Agent, Incorporated in Cheese. Food Chem Toxicol, 46, 2261-2266. 


\section{FIGURES}

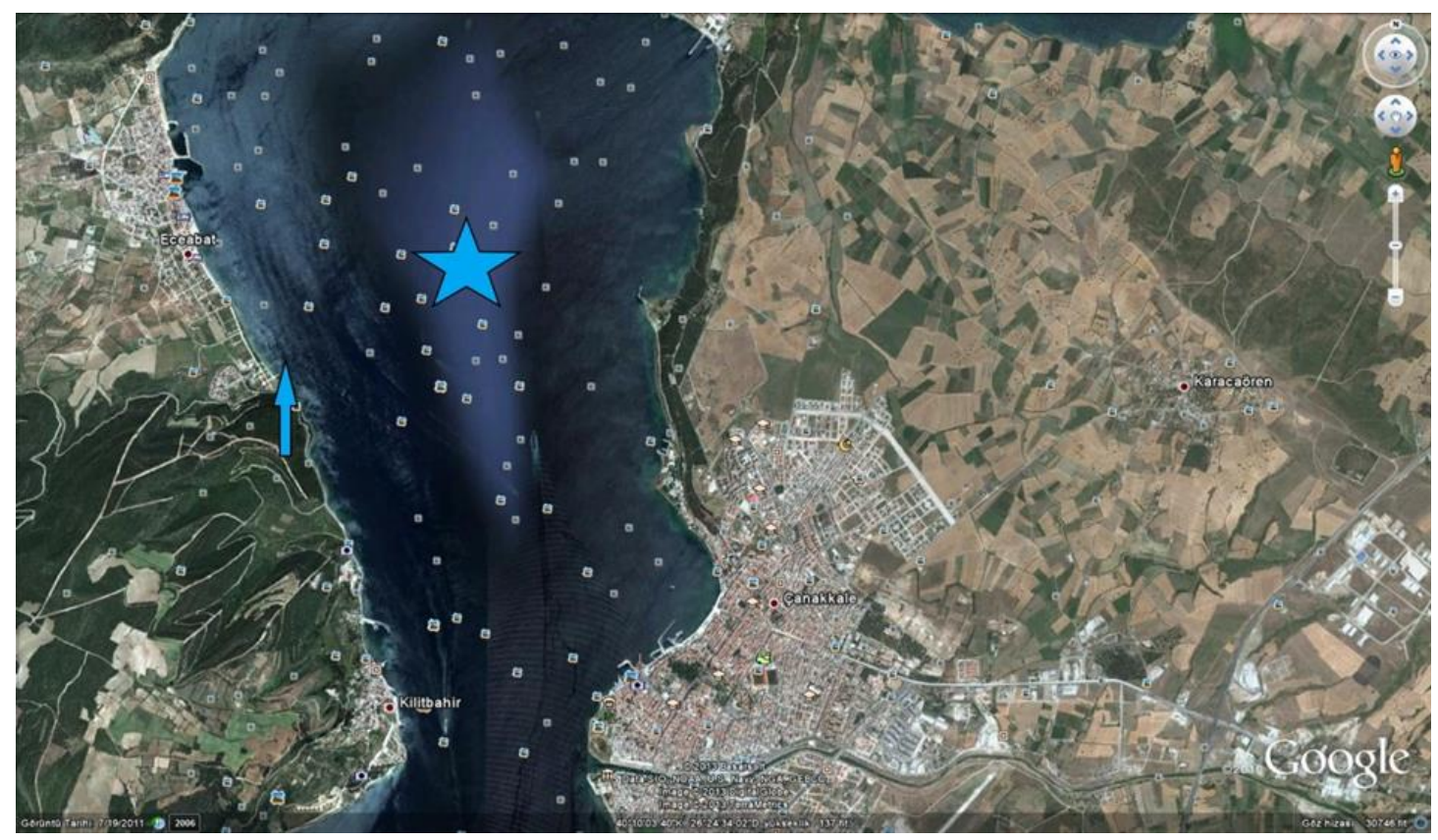

Photo 1. The area where the mussels are collected Arrow: Çamburnu region (Çanakkale, Turkey)

Star: Dardanelles

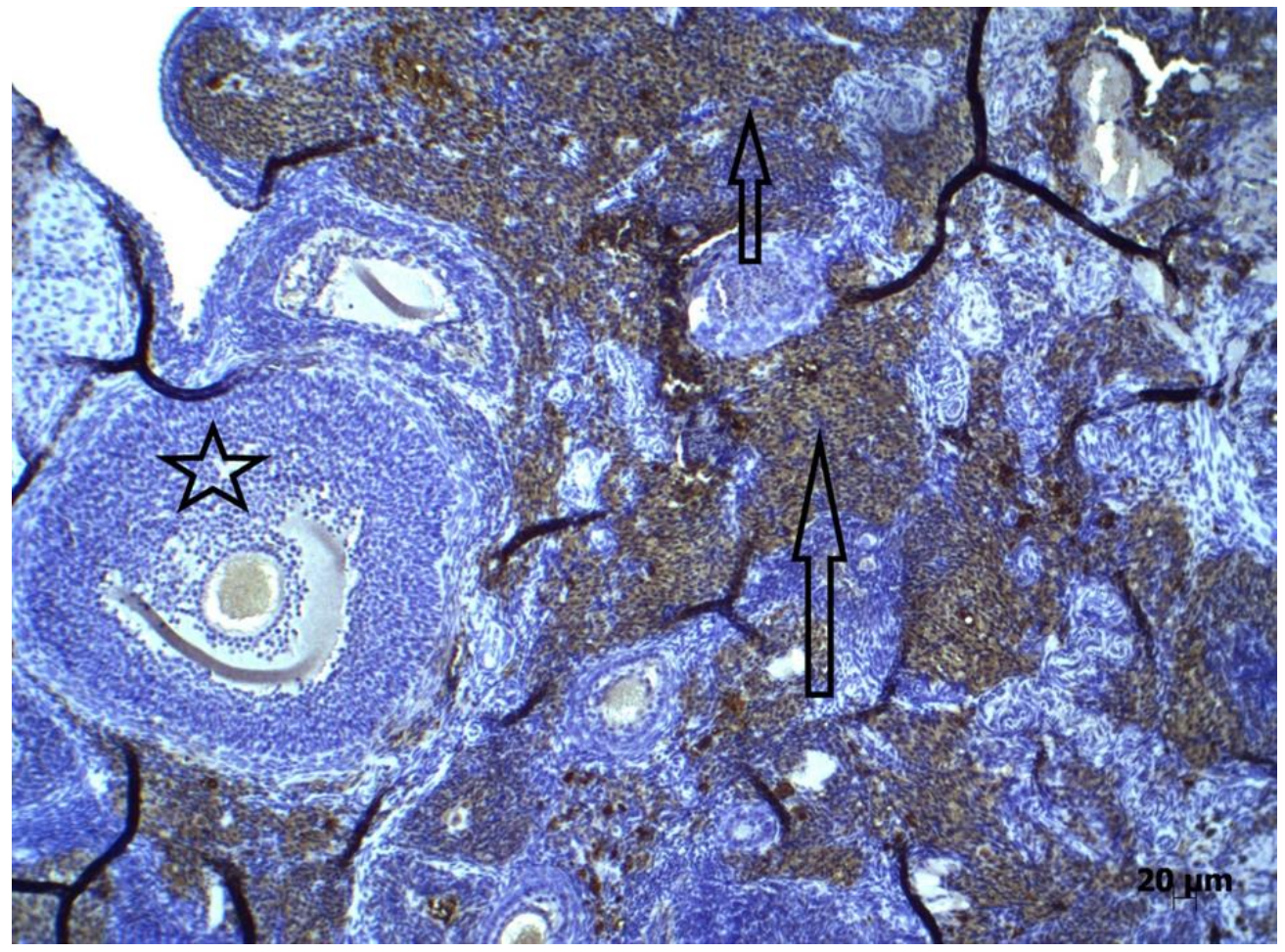

Figure 1. Experimental groups; $90 \%$ mussels $+10 \%$ standard rat diet standard rat feeds were given daily. Rat ovarium, (iNOS x10).

a. Arrow: Positive staining of iNOS in the cytoplasm of interstitial cells,

b. Star: Secondary follicle 


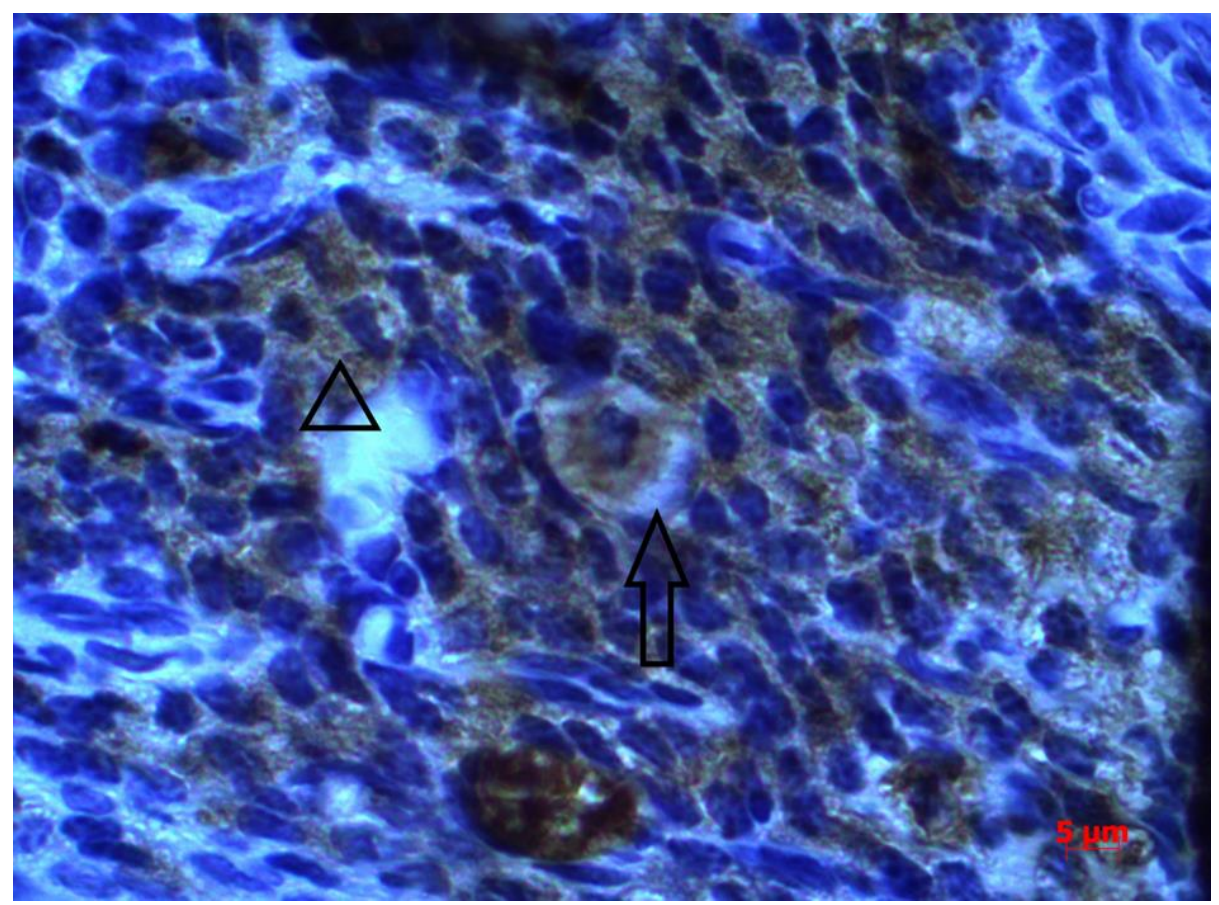

Figure 2. Experimental groups; $90 \%$ mussels $+10 \%$ standard rat diet standard rat feeds were given daily. Rat ovarium, (iNOS x100).

a. Arrow head: Positive staining of iNOS in the cytoplasm of interstitial cells,

b. Arrow: Positive staining of iNOS in the cytoplasm of primordial follicle,

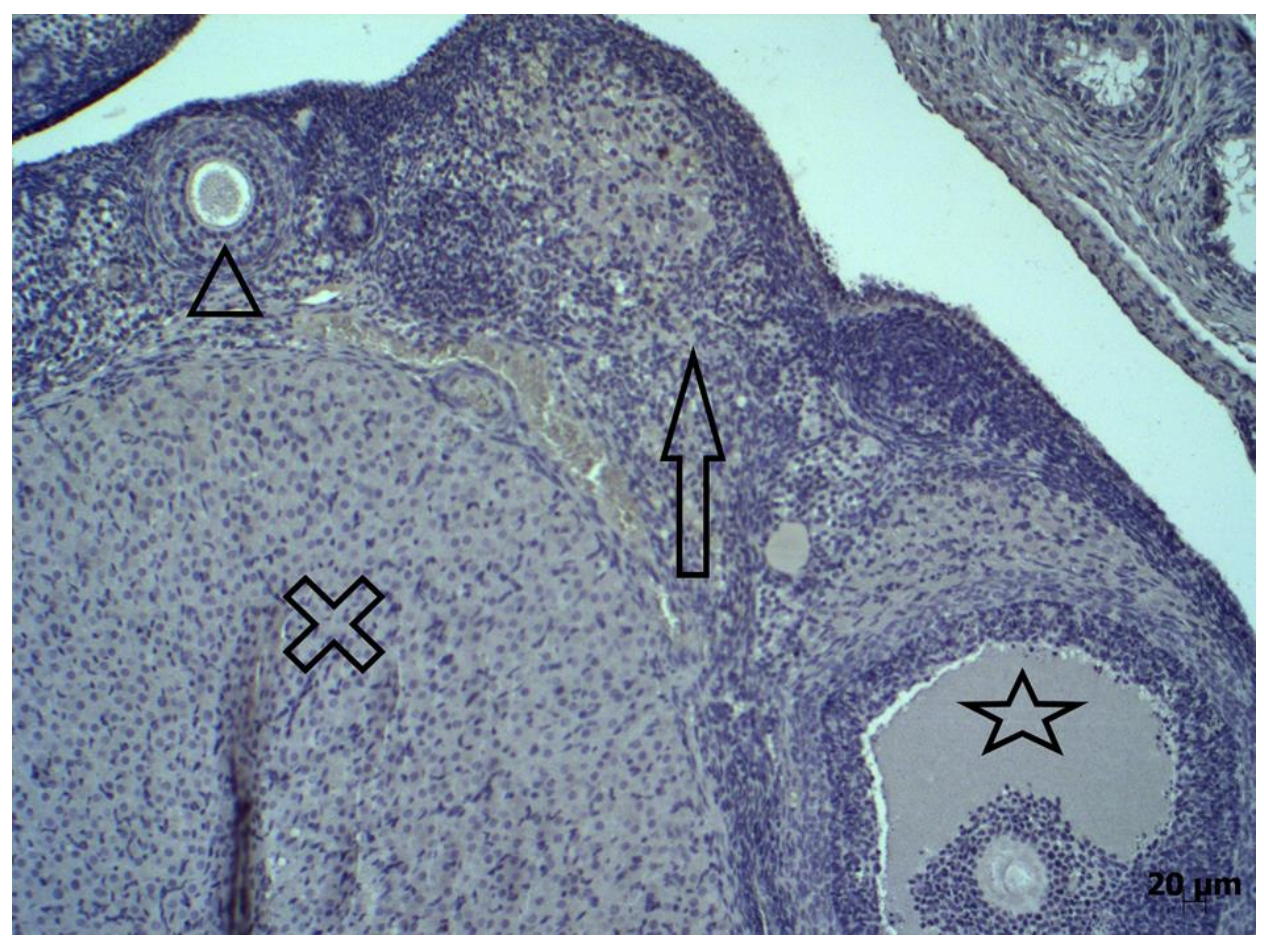

Figure 3. Experimental groups; $90 \%$ mussels $+10 \%$ standard rat diet standard rat feeds were given daily. Rat ovarium, Negative control staining of iNOS

a. Star: Secondary follicle,

b. Arrow: Interstitial cells,

c. Arrow head: Primary follicle,

d. Plus: Corpus luteum, 

galloprovincialis)

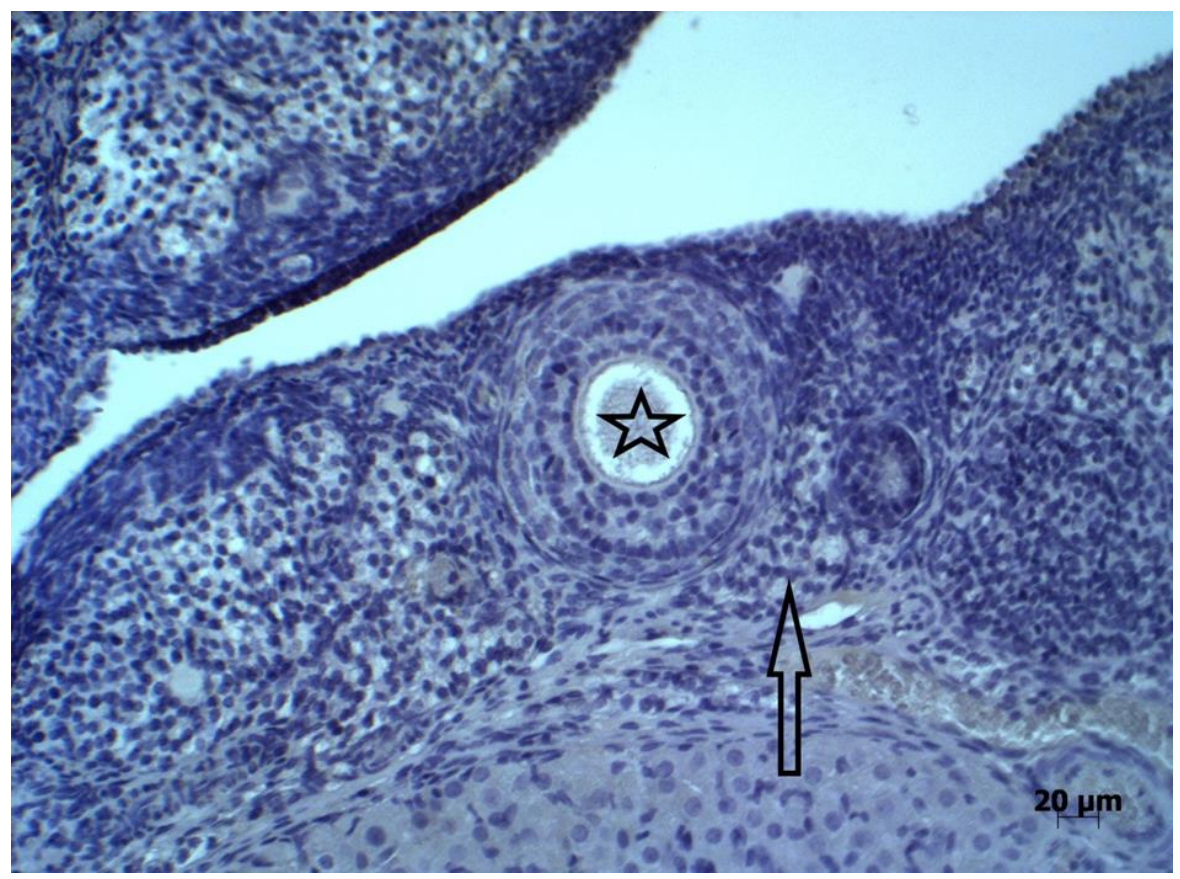

Figure 4. Control groups; $100 \%$ standard rat diet were given daily. Rat ovarium, (iNOS x20).

a. Arrow: Interstitial cells

b. Star: Primary follicle,

\section{Abbreviation:}

iNOS: inducible nitric oxide synthase, NOS: nitric oxide synthase, eNOS: endothelial nitric oxide synthase, CVD: cardiovascular disease, $\mathrm{Al}$ : aluminum, $\mathrm{Pb}$ : lead, $\mathrm{H} \& \mathrm{E}$ : hematoxylin and eosin, nNOS: neuronal nitric oxide synthase, NMDAR: N-Methyl-Daspartate receptor 
GEZEN et al. / iNOS Immunoreactivity in The Ovaries of Rats Feeding with Mussel (Mytilus galloprovincialis) 